\title{
Det moderne gennembruds kvinder
}

\section{En kritisk kommentar}

Pil Dahlerup blev i forảret dr. phil. pá sin afhandling Det. moderne gennembruds kvinder (København 1984). Det følgende er en let omarbejdet version af et indlæg ex auditorio ved disputatshandlingen.

Indledningsvis skal jeg udtrykke glæde ved at den eksisterende forskning indenfor det 19. århundredes danske kvindelitteratur er blevet suppleret med denne omfattende afhandling. Den fremlægger et stort, empirisk materiale om et forsømt område, og den vil være en værdifuld kilde til realoplysninger for fremtidig forskning. Selvom Pil Dahlerup i princippet hylder normative, finlitterært æstetiske normer, har fremstillingen sin styrke $i$ at hun $i$ praksis dispenserer for sin grundholdning og forsøger at foretage en udtømmende behandling af det omfattende emne.

Et så omfattende emne og et så omfattende materiale må selvfølgelig gøre syntetisering og materialeafgræsning særlig vanskelig og rejse en række metodiske problemer. Disse punkter er da også afhandlingens achilleshæl.

Jeg vil i det følgende diskutere nogle problemer i forbindelse med det metodiske udgangspunkt, periodicering og materialeafgroensning.

Efter nogle uprætentiøse metodesynspunkter indledes afhandlingen med et afsnit om hvad der skal blive dens hovednøgle til forståelsen af det efterfølgende: fænomenet Patriarkatet. Selvom Pil Dahlerup benytter en noget esoterisk definition af det $\mathrm{i}$ forvejen lidet veldefinerede begreb patriarkatet, argumenteres der ikke for synspunktet, der blot hæudes. Pil Dahlerup forklarer primært opkomsten af det patriarkalske samfund ved at manden på et vist historisk tidspunkt "alene tillægges evnen til at skabe menneskeliv" (s. 25). Selvom det mátte være tilfældet, at der fra et givet historisk tidspunkt sker en opvurdering af mandens rolle i formeringen, og en nedvurdering af kvindens, er der imidlertid ikke hermed sagt noget om àrsag og virkning. Hvis en understregning af den maskuline 
avling er én af mange virkninger af en bestemt social struktur, kan mandens liv-skaber-monopol kun tillægges en begrænset, afledt og ideologisk funktion. Men Pil Dahlerup hævder uargumenteret, overfor gængse sociologiske, socialpsykologiske og historiske forklaringer, at selve kendskabet til det kvindelige æg, til kvindens biologiske rolle $\mathrm{i}$ formeringen har en afgørende indflydelse på kvindens sociale stilling: Patriarkatet hævdes at stå for fald, efter at man i 1827 opdagede det kvindelige æg.

Denne spekulative forklaring gives der ikke nogen historisk bevisførelse for, og nảr det $\mathrm{i}$ afhandlingen registreres, at kvindernes retsstilling i Danmark forværredes i 1828 (s. 47) forsøges det forklaret ved to helt modsatrettede argumenter: 1 . loven er historisk lidt forsinket, 2. der er tale om et lynhurtigt patriarkatsforsvar. Men hvad værre er: den særlige patriarkatsteori har ingen særlig forklaringsværdi overfor det efterfølgende stof, og samtidig tilslører den de lange linier $\mathrm{i}$ udviklingen af kvindernes samfundsmæssige placering, dens tætte sammenhæng med den sociale og politiske udvikling.

I de socialt mest fremskredne lande som England og Frankrig rejstes der $i$ slutningen af det 18. ärhundrede krav om kvindefrigørelse i forlængelse af den sociale og politiske udvikling, og der var en stærk kvantitativ og kvalitativ vækst $i$ litteratur skrevet af kvinder. Man behøver blot at tænke på Anne Radcliffe og Mary Wollstonecraft. Og netop i det i datiden mest udviklede land, England, er der en jævn stigning $i$ antallet af kvindelige forfattere gennem det 19. århundrede (f.eks. Jane Austen, søstrene Bronté og Georges Eliot for blot at nævne nogle forfattere, der har en fremtrædende finlitterær placering). Áret 1827 spiller ingen særlig rolle i denne sammenhæng, det er bredere kulturpolitiske og sociale konjunkturer, der er afgørende, ligesom kvindernes sociale stilling snævert hænger sammen med landenes sociale udviklingstrin, mens "ægteorien", burde man forestille sig, måtte brede sig til hele den oplyste verden som en steppebrand på tværs af forskel i udviklingstrin.

Iøvrigt benyttes sæd-æg-bestemmelsen hovedsagligt som en slags biologisk forankring af den traditionelle aktiv-mand/passiv-kvindemodsætning, men denne modsætning er i litteraturen såvel før som efter 1827 meget hyppigt knyttet til traditionelt erotisk opspil-og samleje-adfærd og til bredere sociale adfærdsformer (af typen "krig" og "hårdt muskulært arbejde" vs. "yngelpleje"), og det forekommer, at Pil Dahlerups særlige udgave af patriarkatsbegrebet har ringe forklaringsværdi overfor en række af de symbolsk-psykologiske 
problemstillinger $\mathrm{i}$ litteraturen, som den mere socialt og erotisk aktive kvinderolle $\mathrm{i}$ det nittende århundrede giver anledning til og som hyppigt er snæevert knyttet til det erotiske opspil og samlejeadfærden.

Manglen på en bredere, dynamisk historisk ramme for forstảelsen af udviklingen $\mathrm{i}$ kvindernes stilling bliver problematisk, f.eks. i afsnittene om lægevidenskabens mands- og kvindebillede. Selvom det nogle steder $\mathrm{i}$ afhandlingen klart fremgår, at der ikke var én men en række delvis modstridende tendenser indenfor lægevidenskaben, sá fremstilles de mere konservative synspunkter andre steder, som om de var identiske med helheden (f.eks. s. 38: De mandlige læger), pá samme måde som afhandlingen citerer en mindretalsudtalelse i forbindelse med den første kvindes immatrikulation som medicinsk studerende, mens flertalsudtalelsen ikke omtales. Udviklingens fremaddrivende, progressive kræfter er usynlige, andet end som enkeltstáende, tilsyneladende idealistiske kræfter, ligesom de konservative kræfter fremstilles blot som privat fordom uden sammenhæng med de bredere sociale sammenhænge. Begge positioner privatiseres, og spændingerne mellem hierarki-enevælde og liberalisme-demokratisering fremstảr som løsrevne private fordomme og idealismer.

En tilsvarende mangel på en dynamisk, litteraturhistorisk ramme gør sig gældende i materialeafgrænsningen og materialekarakteriseringen. I polemik mod Brandes' afhandling Det moderne gennembruds maend kaldes den foreliggende afhandling for Det moderne gennembruds kvinder. Brandes udvælger en ganske lille gruppe forfattere. Denne lille gruppe, siger han, udgør en enhed ved at besidde en række fællestræk, der gør dem moderne. De adskiller sig derved fra flertallet af de samtidige forfattere. Og Brandes karakteriserer det moderne ved at kontrastere det med de litterære former og holdninger, der var karakteristiske for den foregående periodes litteratur.

I modsætning hertil behandler den foreliggende afhandling alle de kvinder, der er debuteret i tidsrummet 1871-1891. Alle disse kvinders værker omtales som Den kvindelige gennembrudslitteratur. Brandes understreger, at "det moderne" står i konflikt med hovedstrømmen indenfor samtidens danske litteratur og i konflikt med den foregående periodes litteratur. Den foreliggende afhandling derimod lægger vægt pá at understrege, at der trods forskelligheder er en grundlaggende enhed i kvindelitteraturen. Det moderne $\mathrm{i}$ tidsrummets kvindelitteratur fremdrages ved immanent analyse, ik- 
ke i kontrast til de foregående årtiers kvindelitteratur, f.eks. Mathilde Fibigers forfatterskab og emancipationsforestillinger. Afhandlingen betegner enkelte værker som konventionelle, men går ikke ind $i$ en mere udfoldet bestemmelse af tidsrummets litteratur set $i$ forhold til de forudgáende ártiers typiske litterære tematik, fremstillingsformer og verdensbillede.

Dette kan særlig i konklusionsafsnittet opleves som et savn. Her karakteriseres alment den kvindelige gennembrudslitteraturs bidrag til gennembruddet. Men flere af disse karakteriseringer forekommer i højere grad at være typiske for litterære fænomener i de foregáende årtier. Et eksempel: "Set i sammenhæng er symbolopladningen af hverdagselementer den samlede kvindelige gennembrudslitteraturs markanteste svar til datidssamfundet, først og fremmest den samling udskud af dyr, underklasse, farvet race og illegitime, vanskabte og døde børn, der kommer til at repræsentere kvindelighedens a-civilisatoriske stade". Dette form- og symbolsprog forekommer imidlertid at være mere typiske elementer $i$ den romantiske og efterromantiske litteratur, hos mænd som hos kvinder. Og dette formsprog er på retur i de "moderne" kvindelige og mandlige forfatterskaber fra omkring $\mathbf{1 8 8 0}$. I afhandlingen făr da ogsá disse, efter gængs litteraturhistorisk opfattelse, romantisk-efterromantiske elementer, større vægt i materialet fordi Pil Dahlerup bryder sine egne afgræensningskriterier og inddrager en meget læst underholdningsforfatter, Alfhilda Mechlenburg, som debuterede i 1866, altså før 1871.

Tilsvarende omtaler konklusionsafsnittet fremkomsten af kvindelige forfattere og skiftet mellem mandlig og kvindelig jegfortæller som "et kulturchok, der kan sammenlignes med det auditive og visuelle kulturchok, vi i vor tid har oplevet gennem kvindelige radioog tv-speakere. Den tolkende stemme kan væere kvindelig, og det bliver samtidig synligt, at kønnet indgår som et litterært produktionsmiddel." At det var et kulturchok er formodentlig noget præses gætter sig til. For mens der $\mathrm{i}$ afhandlingen og $\mathrm{i}$ anden forskning er givet fremstillinger af, hvordan kvindefrigørelsen $i$ anden af halvdel af det 19. árhundrede forte til kraftige reaktioner, så fremhæver Pil Dahlerup mange steder $\mathrm{i}$ afhandlingen at tidsrummets kvindelitteratur ikke fik den opmærksomhed, den fortjente. En forklaring kunne være at kulturchokket var kommet årtier tidligere. Kvindeforskningen har sảledes vist hvordan Mathilde Fibigers offentliggørelse af Clara Raphael-brevene i 1850 virkede som et voldsomt chok og skabte en omfattende offentlig debat. Og en lille snes 
kvindelige danske forfattere debuterede og skrev i 1850'erne og 1860'erne.

Ligeledes kan man i Munch-Petersens disputats se, at en væsentlig del af de cirka 331 kvindelige forfattere, der blev oversat fra udenlandsk til dansk i det 19. århundrede netop kom til Danmark fra og med 1840'rne, allerede da Olivia Levison og Georg Brandes var børn, havde bibliotekerne og boghandlerne et meget stort antal bøger skrevet af kvinder, og de fleste var skrevet under kvindenavne. Udlandet var på kvindelitteraturens som på mandelitteraturens område forud for Danmark.

Jeg vil nu i forlængelse af det foregående argumentere for, at afhandlingens tidsafgrænsning og behandlingsmåde underbelyser konfliktflader indenfor kvindelitteraturen, ligesom den gør kvindelitteraturens modtagelse mere uforståelig for nutiden, end den var for samtiden.

Næsten hele 1870'ernes danske litteratur lå i direkte forlængelse af de forrige årtiers efterromantiske skrivemåde og forestillingsverden. Denne hovedstrøm var idealistisk-harmoniserende. Samtidens navn for den del af den idealistisk-harmoniserende romanlitteratur, der hovedsagligt var skrevet af og henvendte sig til kvinder var "guvernante-roman" eller "dame-roman". Brødrene Brandes' bestræbelser som kritikere bestod $\mathrm{i}$ at kritisere den harmoniserende efterromantiske litteratur, der havde været progressiv og moderne for årtier tilbage. Men $\mathrm{i}$ begyndelsen havde de ringe held, og først henimod 1880 sker der et massivt litterært gennembrud, det naturalistisk-impressionistiske gennembrud, eller det moderne om man vil.

I nærværende afhandlings afsnit om "døtrene" behandles en række meget forskelligartede forfatterskaber under rubrikken "de moderne", f.eks. Ragnhild Goldschmidts og Olivia Levisons forfatterskaber, der for mig at se falder på hver sin side af gennembrud. det. Afhandlingen omtaler at Edvard Brandes anmeldte Ragnhild Goldschmidts eneste roman, "En kvindehistorie", fra 1875, relativt negativt. Romanen blev, citat "slået sammen med julens øvrige damelitteratur". Negativiteten forekommer Pil Dahlerup urimelig, fordi hun ser Ragnhild Goldschmidt som moderne, og finder at ordet "damelitteratur" er diskriminerende.

Hvis vi imidlertid følger Edvard Brandes' anmeldelse, så benytter han primært ordet "damelitteratur" som en genre-betegnelse, nogenlunde parallelt med brugen af "guvernantelitteratur". De "damefortællinger" han anmelder, anklager han for at udtrykke en snæver og kvindeundertrykkende moralisme, de synes "skrevet til 
advarsel for uartige børn og hårdhjertede gamle jomfruer og anbefaler resignation såvel for børn som for voksne". Én fortælling skildrer f.eks. "et livsglad og lidt pyntesygt pigebarn (...) vips må hendes fader gå fallit". Og på samme måde er Ragnhild Goldschmidts historie for Edvard Brandes udtryk for en bornert moralisme. Min egen læsning af fortælllingen kommer til samme resultat som Brandes: fortælleren slår hårdt ned på den kvinde, der bare viser en anelse selvstændighed, og jeg læser den derfor i forlængelse af 1850 'ernes og 1860 'ernes idealistiske moralisme. Og jeg har vanskeligt ved at følge afhandlingens behandling af historien som udtryk for noget moderne, set i forhold til skrivetidspunktet. At Georg Brandes i 1883 forsøger at tilbagedatere det moderne gennembrud til henimod 1871, forleder Pil Dahlerup til at søge en kun svagt synlig modernitet hos Ragnhild Goldschmidt.

Og modsat med de rigtige moderne som Olivia Levison og Erna Juel-Hansen. Afhandlingen kommer til at underbetone moderniteten $\mathrm{i}$ deres forfatterskaber $\mathrm{i}$ de dimensioner, der har at gøre med deres konfliktfyldte opgør med den efterromantiske litteratur, og dermed de sociale og psykologiske værdier, disse romaner stod for. På samme måde som J. P. Jacobsen under affattelsen af sit bud på en moderne kvindefremstilling i "Fru Marie Grubbe" til tider læste dameromaner $i$ døgndrift både for at lære af og for at overskride disse tidligere kvindefremstillinger, så har Olivia Levison og Erna Juel-Hansen sikkert meget bevidst arbejdet i en frontstilling overfor den tidligere kvindelitteratur.

Dette skel forklarer samtidig hvorfor brd. Brandes anmelder Ragnhild Goldschmidt negativt, hvorimod de anmeldte Olivia Levison og Juel-Hansen uforbeholdent positivt. Og for mit eget vedkommende har jeg, trods kønsforskellen, vanskeligt ved ikke at se et dybt slægtskab mellem to "moderne" naturalistisk-pessimistiske forfatterskaber som Herman Bangs og Olivia Levisons, der adskiller dem fra søskendeparret Goldschmidt. Jeg siger ikke dermed, at årsagerne til deres moderne "psykotiske" pessimisme har helt identiske årsager, men hvis man skulle bestemme de specifikt kvindelige betingelser for den "moderne" pessimisme ville en sammenlignende og kontrasterende analyse af Levison og Bang være en farbar vej.

Mens afhandlingen tenderer mod at udviske brudfladerne indenfor kvindelitteraturen, behandler den til gengæld ikke de sammenhænge og kategoriseringer, der går på tværs af kønsopdelingen. For den umiddelbare oplevelse er der f.eks. en række optimistiske, borgerlige forfatterskaber: Julia Grüner, Emma Gad, Gustav Esmann, 
Sophus Bauditz, og en kontrast til pessimistiske, mere mellemlaglige forfatterskaber som Levison, Bang, Stuckenberg m.fl. Men afhandlingen bestræber sig mere pá f.eks. at tilnærme den tilsyneladende glade Emma Gad til Olivia Levison ved at udkaste som hypotese, at hun er latent depressiv.

Mere generelt kan det siges at syntetiseringskategorierne virker lidet overbevisende, meget gammeldags-vilhelm-andersenske. Det er intimssfærekategorier som "fædre", "mødre", "døtre" o.s.v. der anvendes som syntetiseringskategorier. Det gør det vanskeligt, ja næsten umuligt at følge det litteraturhistoriske udviklingsforløb p.g.a. den næsten manglende historiske kronologi. De tilslører, at firsernes progressive kvindelitteratur hænger sammen med den tilsvarende i halvfemserne, hvorimod halvfjerdsernes hænger sammen med de forrige ártiers kvindelitteratur (note: under forsvaret fremgik det da også, at Pil Dahlerup ikke selv følte sig overbevist af syntetiseringskategorierne, at hun alvorligt havde overvejet at præsentere forfatterskaberne i alfabetisk rækkefølge, hvilket yderligere understreger den atomistiske stofkonception $i$ afhandlingen).

Netop fraværet af historisk ramme muliggør mange steder en subjektiv-associativ fremstilling, $i$ hvilken man føler, at man bliver klogere pá Pil Dahlerup end pá de historiske personer og fænomener, der omhandles. Et eksempel på en sảdan vildtvoksende associationsfremstilling er omtalen af Emma Gads Takt og tone, om hvilken det bl.a. siges, at Emma Gad heri lægger vægt på " $(. .$.$) den$ enkle bevidste handling. Hun ligner hermed ikke blot gestaltpsykologerne og mange nutidige rådgivningscentre for kvinder, men også jeg-psykologerne. "Jeg'et og forsvarsmekanismerne" kunnè bogen ogsả have heddet, men den titel blev brugt at en anden kvinde, Anna Freud (1936)" (afh. s. 465).

Et særskilt problemfelt udgøres af afhandlingens behandling af kvindelitteraturens placering i samtidens offentlighed og i eftertidens litteraturhistorier. I afhandlingens indledning udtrykker Pil Dahlerup vrede over, at periodens kvindelitteratur praktisk taget er fraværende i de litteraturhistoriske fremstillinger, og jeg kan forstå denne indignation. Men Pil Dahlerup retter smed for bager ved at give Georg Brandes skylden for dette forhold, mens den særligt skyldige, Hakon Stangerup, slipper for nærmere tiltale.

Nár Stangerup fjernede kvindelitteraturen fra litteraturhistorien (Politikens litteraturhistorie bd. 3) var det nu ikke alene p.g.a. kvindefjendskhed, men udtryk for en "smal" litteraturopfattelse, hvor kun et fátal af finlitterære forfatterskaber fik adgang til littera- 
turhistorien, mens Vilhelm Andersens brede omtale af litterære fænomener, masselitteraturen, kvindelitteratur, skolelærerlitteratur m.v. blev udgrænset.

Det er nu afhandlingens eksplicitte tese, at nảr kvindelitteraturen ikke forefindes i litteraturhistoriske fremstillinger, skyldes det i høj grad Georg Brandes' manglende offentlige indsats for den, og det er afhandlingens implicitte forudsætning, at Georg Brandes har haft en afgørende indflydelse pá senere litteraturhistoriske fremstillinger af hele tidsrummets litteratur. Jeg vil i det følgende argumentere for, at Georg Brandes kun i meget begræenset omfang har haft indflydelse pà de senere litteraturhistoriske fremstillinger af litteraturen i Danmark fra og med 1880, hvor den moderne kvindelitteratur fremkom.

Pil Dahlerup hæfter sig ved at "Georg Brandes i perioden 18711891 ikke anmeldte én dansk kvindelig forfatter. Han skrev et forord til Adda Ravnkildes "Judith Fürste" i 1884, men det var karakteristisk nok - samtidig en nekrolog". Afhandlingen giver en række psykologiske og biografiske begrundelser for dette forhold og argumenterer for, at Georg overlod det til sin broder Edvard, reservefiltret som han kaldes, at være hovedanmelderen af periodens kvindelitteratur (s. 128). Man kunne nu tro, at Georg Brandes var hovedanmelderen af den moderne danske mandelitteratur, men det er ikke rigtigt. Også mandelitteraturen var Edvard i den omtalte periode hovedanmelder af. Georg var primært anmelder af udenlandsk litteratur, med nogle undtagelser, mens Edvard tog sig af dansk litteratur. Men iøvrigt var brd. Brandes nok mere forskellige i stil end i litterære holdninger og vurderinger. Så når alle, der kunne forvente en, positiv anmeldelse hellere ville anmeldes af Georg, var det fordi hans sjældne anmeldelser af danske bøger gav de udvalgte en særlig status.

I sine anmeldelser ledte Georg således de udenlandske hovedstrømninger ind i Danmark. Markante undtagelser fra denne regel er, at han af og til i begyndelsen af $1870^{\prime}$ 'erne anmeldte vennerne fra de unge ár: Jacobsen, Drachmann og Schandorph. Som fremstillet $i$ Stangerups - iøvrigt hadske - disputats, var Georg Brandes omkring $1883 \mathrm{i}$ en social krise. De fire radikale på venstrebladet Morgenbladet, Georg og Edvard Brandes, Hørup og redaktionssekretær Erik Skram var meget isolerede, og de måtte ved árets udgang forlade bladet. Det var i denne socialt pressede situation, at Brandes affattede Det moderne gennembruds mand, der skulle demonstrere hans egen betydning for de moderne strømninger, som tog fart 
omkring 1880. Han samlede og omskrev anmeldelserne af vennerne fra ungdomsårene (Jacobsen, Drachmann og Schandorph) og tilføjede udover de to norske koryfæer Ibsen og Bjørnson, kun de to litterater og daglige omgangsfæller fra Morgenbladet, broderen Edvard og Erik Skram. Men han medtog ingen af de forfattere, der var debuteret omkring 1880, og som nok så meget-kom til at tegne den moderne linie i dansk litteratur. Der var gode grunde til ikke at medtage Topsøe. Men han medtog ikke den senere nobelpristager Gjellerup, der havde udgivet adskillige romaner og en digtsamling. Han medtog heller ikke Bang, der havde udgivet adskillige bøger, så lidt som han medtog Pontoppidan, der var debuteret i 1881 med en novellesamling, som Brandes privat udtrykte tilfredshed med. Og han medtog ikke Olivia Levison, der udgav sin første moderne novellesamling i 1881, så lidt som Erna Juel-Hansen, der debuterede i 1881 . Det vil sige, han medtog ingen af de moderne forfattere, der var debuteret indenfor de sidste par år for udgivelsen af Det moderne gennembruds mond. Jeg tror det er usandsynligt, at Brandes overhovedet overvejede at optage debutanter som Pontoppidan og Juel-Hansen.

Men hvad mere er, han anmeldte formodentlig overhovedet ikke Pontoppidan i de næste 25 år. Han havde en lille Bang-anmeldelse henimod århundredeskiftet, og bortset fra en anmeldelse i 1883 behandlede han heller ikke Gjellerup. Derimod skrev han nekrolog over Levison og en smuk anmeldelse af Juel-Hansen i 1894. Så hvis Georg Brandes' behandlinger havde været normgivende for senere litteraturhistorier, var Pontoppidan slet ikke blevet taget med, hvorimod Levison og Juel-Hansen havde fået behandlinger på størrelse med behandlingen af Bang. Og hvis brd. Brandes' anmeldelser havde ligget til grund for senere litteraturhistorier, burde disse kvindeforfattere have haft en langt storre placering i litteraturhistorierne end Topsøe.

Det forhold at flere kvindelige forfatterskaber får deres behandling i form af nekrologer, får Pil Dahlerup til at give en psykologisk forklaring: nemlig at Brandes skulle lide af såkaldt "tristanisme". Men der er en enklere forklaring: nemlig at Brandes i 90'erne og det nye århundrede var et monument, der sædvanligvis ikke skrev dagtil-dag-anmeldelser, men derimod oversigtsartikler om udenlandske fænomener, nekrologer over store udenlandske og danske mænd og kvinder, jubilæumsartikler o.s.v.

Afhandlingen ser Det moderne gennembruds mond som en dominanserklæring overfor kvinderne, bønderne og arbejderne. 
Blandt mange argumenter herimod kan man fremføre, at den eneste af Schandorphs romaner, som Brandes i Det moderne gennembruds mæend syntes virkeligt godt om, markant bedre end senere litteraturhistorier, var romanen "Smaafolk" . Den handler om mændenes tåbelighed og har som heltinde en tjenstepige, der til slut, sammen med andre kvinder, laver et kvinde-produktionskollektiv, så de er fri for at være afhængige af mændene.

Pil Dahlerup mener i Brandes' Lassalle-bog fra 1881 at kunne hente belæg for, at han i begyndelsen af 1880'erne følte mandigheden truet af kvinderne. Man kan af Brandes' "iscenesættelse og tolkning af Lassalles skæbne se, at den største trussel mod mandlig. heden for Brandes i 1880'ernes begyndelse var kvinderne - hvis man vel at mærke ikke forstod at styre forholdet til dem. Det forsøgte Brandes med Det moderne gennembruds maend - og i sin kritikervirksomhed over for "det moderne gennembruds kvinder". Jeg læser imidlertid Lassalle-bogen som følger: den tyske socialistleder Lassalle forelsker sig i en ung pige med emancipationsønsker. Da hun anmoder Lassalle om at flygte sammen med hende over grænsen til Frankrig, for at hun kan komme fri fra sin formynderiske familie, opfører Lassalle sig slapt-spidsborgerligt. Han forsøger i stedet for flugt at opnå forældrenes samtykke. Men som Brandes skriver: "nu brød Faderens raseri ud over den unge pige. Han trak hende ved hårene og stødte hende over gaden til sit hus, indespærrede hende" . D.v.s. Brandes anklager Lassalle for at have svigtet en kvindes emancipationsønsker. Da Lassalle så opdager, at han ikke kan få faderens samtykke, opfører han sig tåbeligt, benytter sin gamle elskerinde som forbindelse til den unge pige og udfordrer pigens fader og den designerede ægtemand til duel, og dør i en sådan.

Som jeg ser Georg Brandes, var han i sit offentlige virke fast forankret $\mathrm{i}$ ønsket om kvindens frigørelse og ligestilling, mens han $\mathrm{i}$ sit hjem, som Pil Dahlerup så rigtigt dokumenterer $\mathrm{i}$ afhandlingen, havde vanskeligt ved at leve op til sine idealer.

Derimod er der særlig fra slutningen af $1880^{\prime}$ erne og i 1890'erne nok af andre mænd, andre forfattere, der reagerede med en patologisk og diktatorisk kvindeangst. Ikke så meget forårsaget af kvindelitteraturen - efter min mening - men mere pả grund af den faktiske og accellererende kvindefrigørelse i samfundet. Og senere litteraturhistorieskrivere synes at have taget disses parti.

Overhovedet viser Brandes-fremstillingen mange af svaghederne ved afhandlingens atomistiske tilgang. Brandes sættes ikke ind i en historisk/litteraturhistorisk helhed, men fortolkes udfra punktana- 
lyser - der endda fremstilles ukronologisk, først Brandes 1883, så $1870 \mathrm{og}$ endelig 1901. Selvom fortolkningen af Lassalle-bogen er væsentlig for argumentationen, redegøres der ikke for dens historie (selvom store dele havde fáet en første publikation allerede i Det 19. drhundrede og var udkommet på tysk i 1877). Intime og erotiske motiver foretrækkes uden at være blevet afvejet med sociale, privatbreve m.v. benyttes uden at være blevet underkastet en kildekritisk vurdering o.s.v. Og der er ingen redegørelse for den offentlighed, der ikke var brd. Brandes, og som f.eks. sikrede Topsøe og Bang en placering i senere litteraturhistorier.

Fremstillingen af den litterære offentlighed i perioden bliver dobbelt fordrejet dels ved at brd. Brandes tildeles en indflydelse, der er helt ude af proportion - selvom de er valgt som eksempler, fremstảr de mange steder $\mathrm{i}$ fremstillingen næsten som om de var den litterære offentlighed - og dels ved at de fremstilles med en let dæmoniseret psykologisme. Det er i den forbindelse ironisk at Pil Dahlerup pả en række punkter, særlig i sit Edvard Brandes-portræt ligger i forlængelse af Hakon Stangerups partiske fascineret-dæmoniserede Brandes-portrætter, når man betænker, at det var samme Stangerup, der fjernede den kvindelitteratur, som Brandes havde gjort så meget for at ophjæelpe, fra litteraturhistorien.

Afhandlingen vil ikke have sin værdi for eftertidens forskning ved sine teser og metodiske greb, ikke mange holder for en nærmere prøvelse, men derimod som et værdifuldt empirisk materiale. Pil Dahlerup har medvirket til at genindføre kvindelitteraturen i litteraturhistorien. Og afhandlingen har samtidig været med til at demonstrere problemerne ved den smalle litteraturhistoriebeskæftigelse, der kun registrerer den litteratur, der på et givet tidspunkt falder indenfor snævre æstetiske kriterier. Afhandlingen har forsøgt at trænge ud $\mathrm{i}$ krogene af det litterære landskab og forsøgt at afpresse også tilsyneladende marginal litteratur betydning, set den som menneskelige dokumenter. 